\title{
THE MANAGEMENT OF INDUSTRIAL INTERNSHIP
}

\author{
Sujarwo $^{1}$ YettiSupriyati $^{2}$ \\ Center for Environment and Forestry Education and Training of Makassar ${ }^{1}$ \\ State University Of jakarta ${ }^{2}$ \\ jarwobdk@yahoo.co.id \\ yettisupriati@unj.ac.id
}

\begin{abstract}
The research objective was to determine of Industrial Internship consisting of planning, organizing, actuating, controling and monitoring.This is a qualitative research by employing a case study method which was conducted at public vocational senior high school (SMK Negeri 5) Makassar from April 2013 to September 2016. Interviews, document review, and direct observation were taken for data collection while the validity of the data was measured by using triangulation of source and technique. For data analysis, the stages of reduction, data display, and conclusion were used. The results show that 1)Planningof Industrial Internship has not been implemented optimally; such as curriculum validation and mapping the business and industrial were not well-conducted by the school; 2) Organizingaspectsof industrial internshipwere less than optimal implemented, such asarranging ofIndustrial Internship committee was not equipped clearly with the structuring of tasks, job descriptions and distribution of authority. In addition, appointment of school instructur is simply to accommodate the interests of educators with the principle of equity not competency; 3) In actuating aspect, learning by doing and learning by experience were not optimal since the location of industrial internship did not meet the school's need; 4)Controlling and monitoring Industrial Internship were not optimal as well since the teachers as instructors did not control the students' activities continously. To sum up, the industrial internship conducted in vocational high school must obtain serious attention by the school, industry and government as to improve the students' knowledge and skills. Additionally, the school, industry and government are required to collaborate and synergize optimally for the sake of students' improvement.
\end{abstract}

Keywords: Industrial Internship, Learning by Doing, Learning by Experience

The city of Makassar is listed as the city with the highest unemployment rate in South Sulawesi which reaches $11 \%$ of the total labor forces of 651 thousand people per year (Fajar, January 30, 2017). Based on the research of The Education Sector Analytical and Capacity Development Partnership (ACDP), it is mentioned that generally, the business and industry have not been satisfied with the competence of school graduates from high school/vocational high school to college. There is a mismatch between the skill of graduates andthe needs of the business and industry. Whereas at the same time many companies plan for more expansion and require manpower (Kompas, 17 October 2016).

The above conditions open up the possibility of discourage unemploymentfrom vocational graduates who have been looking for work for years without results because demand factors for labor and labor supply are increasingly unbalanced. Among vocational graduates, this category of 
desperate unemployment is predicted to grow larger. They are ready work job seekers, but apparently the existing labor market doesn't likely seem friendly (Suyanto, 2016).

Vocational Secondary Education is an education that prepares students to be able to work in certain fields (Law No. 20 in the year of 2003). Government regulation no. 19 in the year of 2005 explained that Vocational Secondary Education is an education at secondary education level that prioritizes the development of students' skills for certain types of work. Their task is to prepare students with the competencies and skills of certain fields, so that after graduation, they can work on a particular field independently or to fill vacancies in the work.

The vocational education approach model is known as Dual System Education, which operationally, the model is called Industrial internship. Industrial Internship is an educational model of vocational skills that combines systematically and synchronously between school education and learning programs through direct work activities in the relevant field of work in the business and industry and other institutions directed to achieve mastery of certain skills. The laborsare requested to have the level of knowledge, skills, and work ethic which are appropriate with job demands (Pakpahan, 2002).Considering the importance of Industrial internship, good Industrial Internshipmanagement is required as one of the strategies in managing cooperation between vocational schools and the businessand industry, which aims to produce graduates who have link and match competence with the needs of the job (Djojonegoro, 1999).

Industrial Internship is an activity undertaken by learners in the form of direct practice in the real work done by apprenticeship in the industry relevant to the expertise program. Pozaic(2009) said Internships usually refer to practical training for students during or after the completion of their studies. They may or may not be related to a particular occupation but when they are a compulsory part of practical experience which has to precede professional employment. They are very different from internships where the main purpose is to expand specific knowledge in some field which is the focus of a thesis or as a way of finding one's way into a company of choice for employment.

Industrial internshipor On the Job Training (OJT) is a training model conducted in the field, aiming to provide the skills needed in a particular job in accordance with the demands of the ability for the job (Hamalik, 2007). The objectives of the Industrial internship include: 1) producing professional-skilled workers 2) improving and strengthening link and match between educational institutions and vocational training 3) improving the efficiency of professional quality education and job training by utilizing available training resources in the work, and 4) recognizing and rewarding work experience as part of the education process (Djoyonegoro, 1999).

SMKN 5 Makassar is one of the vocational schools that organizes different vocational education programs compared to other vocational schools in Makassar. Characteristics of education in SMKN 5 Makassarare: 1) education process last for four years, while others last for three years, 2) the implementation of Industrial Internshiplast for 6 to 8 months, while others last for 3 months, 3) SMKN 5 Makassar is the only vocational school in Makassar that has cooperated in MoU scheme withbusinessand industryin Industrial Internship implementation for certain type of competence.

Based on the above description, the research question focuses on how to apply the management of Industrial internshipin SMKNegeri 5 Makassar whichthe aims are to examine: 1) Industrial Internship planning, 2) Industrial Internship organization, 3) Industrial Internshipactuating, and 4) Industrial Internshipmonitoring and controlling.From this research, it is expected to find out the management of Industrial Internshipat SMK Negeri 5 Makassar South Sulawesi. Besides, the result of this study is expected to be useful to improve the management of Industrial internship, particularly in Building Engineering in SMK Negeri 5 Makassar. 


\section{METHOD}

This is a qualitative approach by employing case study methodwitha single case holistic design (Yin, 2003). The focus of this research is the management of Industrial Internship at SMK Negeri 5 Makassar South Sulawesi majoring in Building Engineering.Data collection wasconducted by interview, observation and documentation study. In qualitative research the researcher functions as the key instrument that does grand tour observation firstly and collects the data from many sources.Sources of data fromthe key informants are:principal, vice principal in the division of industrial relations, vice principal in curriculum divison, the head of program study, productive teachers, parents (school committee, students and instructors from industry and business. Data analysis was conducted qualitatively with reference to Miles and Huberman (1994: 8) which included data reduction, data presentation, and conclusion / verification. Triangulation of sources and techniques were employed for data validity. The research period is 1 year from January 2016 until December 2016at SMK Negeri 5 Makassar South Sulawesi.

\section{RESULTS}

The results showed that the implementation of Industrial Internship at SMKN 5 Makassar was executed as an implementation of education policy, among others: 1) Government Regulation No. 29 of 1990 on Secondary Schools Article 3 Paragraph (2); 2) Decree of the Minister of Education and Culture No. 323 / U / 1997 on Dual System Education Article 1 Paragraph (2), 3) Law Number 20 Year 2003 on National Education System, 4). Educational unit level curriculum of vocational high school in 2004 and 5).Government regulation no. 17 of 2010 on Management and Implementation of education Article 76 paragraph (2) point c.

Industrial Internship planning begins with curriculum validation activities, businessand industrialmapping, Industrial Internship modeling, supplies, and guidance. Industrial Internship Planning is not implemented optimally by involving stakeholders in the implementation of Industrial Internship. Curriculum validation is not done by involving the business and industryl. Mapping the business and industrial is less systematically conducted related to the feasibility and suitability of Industrial Internship location with the needs of Industrial Internship. Industrial Internship debriefing is carried out for five days with material on general matters related to Industrial Internship, work ethic, order, reporting, and job technique in business and industry.

The organization of Industrial Internship activities is carried out with the following activities. Firstly, establishment of Industrial Internship team work. One informant said that such a condition occurs because Industrial Internship activities are routine activities that have been implemented for many years so that the teachers have already experiencedbeing the committee. Industrial Internship organizing committee members are not equipped with the structure of tasks, authority, and clear division of tasks among the committees. Secondly,determination of Industrial Internship guidance.Determination of Industrial Internship's supervisor applies the principle of equity. That is, Industrial Internship counselors are not only productive subject teachers, but also normative, and adaptive subject teachers, even administrative staff. To eliminate possible weaknesses of the school recruitment system, advisors are appointed from the partner institution that guides the students during the implementation of Industrial Internship.

Industrial Internship management, especially the actuating aspects of Industrial Internship has not gone well. The placement of students at locations is less representative in the area of expertise being studied. Thus, students often do unrelated activities to the field of expertise, which they have learned in the school. It is an indication of the weakness of Industrial Internship management aspects in the function of the actuating activity. 
Controlling and monitoring activities of Industrial Internship's implementation are rarely performed by school counselors. Monitoring activities are only carried out at the beginning of student placement, in the mid of Industrial Internship, and at the end of Industrial Internship when students will be withdrawn from Industrial Internship location. The function of controllingand monitoring on the implementation of Industrial Internship activities is not run optimally. Monitoring as one of the instruments to control the implementation of Industrial Internship activities becomes less functional.

\section{DISCUSSION}

Legal protection in the implementation of Industrial Internship activities in SMKNegeri 5 Makassar before, during, and after the period of regional autonomy always refers to Ministry of Education and Culture Number 0490 / U / 1992 about SMK cooperation with the business and industry. Dual System Education Program is implemented based on Ministry of Education and Culture Number: 323/ U/ 1997 on the Implementation of Dual System Education (PSG) in Vocational High School.

Article 2 Ministry of Education and Culture Number 323 / U / 1997 states that Dual System Education aims:

1. Improving the quality and relevance of vocational education through the role and industrial partner;

2. Producing graduates who have the knowledge, skills and work ethic that are in line with work demands;

3. Producing graduates who have the knowledge, skills and attitudes that are the basic foundation of their own sustainable development;

4. Giving recognition and respect for work experience as part of the educational process;

5. Improving the efficiency of vocational secondary education through the empowerment of education in the world of work.

Implementation of Dual System Education is essentially an implementation of Government Regulation of the Republic of Indonesia Number 39 of 1992 on Public Participation in National Education. Article 2 of Government Regulation no. 39 of 1992 states that the role of the community functions to participate in maintaining, improving and developing national education. The purpose of community participation in national education is contained in article 3 which states that community participation aims to utilize the existing ability of society for education to realize the goals of national education. Law No. 20 of 2003 on the National Education System article 9 states that the community is obliged to provide resources support in education implementation.

Concretely, the form and the role of community participation in national education are listed in Article 4 point 8 of Government Regulation No. 39 of 1992, namely the provision of opportunities for internships and or work training. While the role of community participation can be done by individuals, groups, or entities that are not part of the government.

Based on the research findings, it is known that none of the business and Industryis currently willing to cooperate with schools formally and bind through the scheme of agreement (MoU) signed by both parties. The reason is the business and Industrial does not want to be bound by the contract in the agreement and bound by obligations and responsibilities to accept Industrial Internship students every year.Whereas, in developed countries, the role of industry is demonstrated in the form of program cooperation, financial support for research and scholarship. Even in some countries, the role of this industry has become an obligation because there have been laws that regulate it. At least the business and industry that have actually established cooperation with schools are given incentives by providing tax breaks (Pardjono, 2011). 
Implementation of industrial internship as an innovative educational pattern that synchronizes the demands of the business and industry with the curriculum of education in vocational high school needs to be followed by clear and operational guidelines and technical guidelines. Particularly since the enactment of Law No. 23 of 2014 on Regional Government, the strengthening of formal juridical aspects through Regional Regulation or Governor Regulation becomes one of the instruments to improve the quality of industrial internship in vocational schools.Presidential Instruction No. 9 of 2016 provides a very strong and clear justification to the relevant ministers and all governors to revitalize vocational high school through various operational policies to improve the quality of learning in vocational high schoolincluding the implementation of Industrial Internship. Government Regulation of the Republic of Indonesia Number 17 Year 2010 concerning Management and implementation of Education Article 17 states that the governor is responsible for managing the national education system in the region and formulating and establishing regional policies in the field of education according to their authority.

The authority granted by Government Regulation Number 17 of 2010 to the governor related to the regional policy in the field of education can be set forth in the regional regulations in the field of education or governor regulation in the field of education. Local policy in the field of education can be a guide for all education stakeholders in each province. Especially with the enactment of Law No. 23 of 2014 on Regional Government Article 15 paragraph 1 and 2 and Attachment Letter A on the division of Government Affairs of Education in sub-affairs of Education management.

Based on Presidential Instruction No. 9 of 2016, the President commands Governors to:

1. Provide convenience to the public to get a qualifiedvocational school of education services in accordance with the potential of their respective territories.

2. Provide educators, education personnel, adequate and qualified facilities and infrastructure of vocational schools.

3. Conduct institutional arrangements of vocational high schools includingavailable vocational programs and locations of vocational schools; and

4. Develop excellent vocational schools in accordance with the potential of each region.

If there is a legal protection in the form of local government regulation or governor regulation concerning the responsibility of the business and industry in supporting the implementation of vocational secondary education, especially related to the implementation of industrial internship, it will be a driving factor for the increasing quality process and result of Industrial Internship activity. Legal protection is required for all education stakeholders, especially the business and industrial to have a juridical and moral responsibility in improving the quality of vocational secondary education.

The research findings have revealed that Industrial Internship planning is not implemented optimally by involving the stakeholders in the implementation of Industrial Internship. Curriculum validation is not done by involving business andindustry. Mapping the the business and industryareless systematically implemented related to the feasibility and appropriateness of Industrial Internship location with the needs of Industrial Internship. Appointment of Industrial Internship's controlling is done with the principle of equity.Whereas, the implementation of Industrial Internship refers to the Demand-Driven system based on the needs of the labor market. Under the system, vocational education programs are derived from the real needs of the job market. To be able to realize the program, then the role of business andindustry is highly needed (Sidi, 2001). To meet the needs of the businessand industry, companies require changes in term of vocational programs.Billett (2011) explains that indeed, to meet their particular needs for economics efficiency, enterprises want two levels of customisation of vocational programmes. First, they want the curriculum to be 
customised to their industry by creating a range of modules from which they can choose those which pertain to their workplace. Secondly, they want the modules themselves to be made more workplace specific.

Ministry of Education and Cultureshould strive for the vocational school curriculum in accordance with the skills required by the business andindustry. It should also be ascertained that $70 \%$ of on the job trainingis done together with the right industrial partners (Kompas, 17 October 2016). Since current vocational school conditions require reinforcement. Presidential Instruction No. 9 of 2016 on the revitalization of vocational school becomes very imperative. Its Revitalization of vocational school requires industry involvement as a user. Therefore, the preparation of the curriculum must be side by side with industry or association. Vocational education should be able to provide a solid basis for personal, socially oriented labor market development. Bohlinger (2015) argues thatiIn vocational education and training (vet), one of the core challenges is the matching between demand and supply, i.e. linking educational profiles and qualifications with labour market needs and positions. The extent to which vocational education and training can provide a sound basis for an individual's personal, social and labour market oriented development depends on a number of factors.

The result of the 2015 ESSA meeting states that partnerships between vocational education institutions and employers can improve the quality and relevance of work-based learning.It is said that one of the key requisites of successful work-based learning is the engagement of employers in the design and delivery of training programmes. In this session, delegates from the Philippines, Cambodia, Malaysia and Thailand shared strategies and experiences on how they leverage public-private partnerships to strengthen the quality and relevance of work-based learning and TVET.Schools as a social entity must also be managed with good management so that all potentials and resources can be empowered in the achievement of educational goals. Organizing in school activities related to all aspects of both curricular and co-curricular activities can improve the quality of education processes and outcomes. Good organizing will have implications for good coordination among departments within the school organization.

Wellorganized management in Industrial Internship organization is one of the determinants of the quality of Industrial Internship's process and outcomes. In a modern perspective, one of the management functions is leading which according to Bateman and Snell's perspective is mobilizing people. Leading according to Bateman and Snell (2002) is the management function that involves the manager's effort to stimulate high performance by employees. Hence, good human resources must be mobilized so that they can display their high performance. The management has an authority attached to its position to perform such management processes in order to achieve the organization's objectives.

One of the key elements of any successful manager is his ability to handle everyone effectively. Mullins (2005) asserted that managers must be equipped with social skills and ability to build relationships between people.There are many aspects to management in work organisations, but the essential ingredient of any successful manager is the ability to handle people effectively. the manager needs to be conversant with social and human skill, and have the ability to work with and through other people. Without people there can be no organisation and no meaningful activity.

In the context of industrial internship in SMKNegeri 5 Makassar, ideal Industrial Internship organization is also followed by the structure of duty and authority distribution in a clearly written. A good working team is formed because of having the clear distribution of authority and responsibility on all components within the school organization. In smaller structures, clear authority and responsibility of the Industrial Internship committee, followed by a range of controls and controls by 
the management will have implications for the effectiveness of Industrial Internship's organization. As Daft (2008) explained that organizinginvolves assigning tasks, grouping tasks into departments, delegating authority, and allocating resources across the organization.

Industrial Internship participants' placement activities are the next step which is carried out as a series of implementation process of Industrial Internship program. The process of industrial internship is carried out by students in the business and industry large, medium or small scale. In the implementation of industrial internship, the processes and steps of implementation practice still refer to the established learning design.In order to obtain the required standard of competence of expertise, Industrial Internship activities must be carried out in the appropriate business and industry. This is in line with the results of Vaughan's research that industrial work practice is a learning process implemented in the actual workplace that serves as a study room. Learners are in real situations and real consequences. The results show that the workplace provides not only a rich learning context, but also a rich learning experience. Vaughan (2012) suggests that the defining features of learning in the workplace relates to its authenticity as a site of learning. Learners are dealing with real situations, real customers, real deadlines and real consequences. Research has shown that workplace provide, not just rich learning contexts, but also deliberately constructed rich learning experiences.

To improve the implementation process of Industrial internship, implementation management must be optimized. The aspect of management isrelated to the control function of all activities of the practice which the purpose of control is to avoid unpleasant surprises that may occur as stated by Dessler (2001) that control is the task of ensuring that activities are providing the desired results. In its most general sense, controlling means setting a target, measuring performance, and taking corrective action as required. The goal of the control system is to have no unpleasant surprise in the future.

Based on those data, it can be concluded that the process of controlling and monitoring is carried out only limited to the activities of delivering, visiting, and picking up students. The overall guidance and monitoring activities are more ceremonial without the controlling and monitoring of Industrial Internship implementation. Whereas Gessler and Hinrichs (2015) explain that monitoring the learning transfer of continuing vocational training is therefore crucial in order to control the training success and legitimate the investments made. It is not surprising that the design of training measures is currently leading the list of challenges within vocational training.

Based on the study of management aspects, it is necessary to conduct evaluation activities throughout the program cycle. In the context of the implementation of Industrial Internship at SMKNegeri 5 Makassar, evaluation can be applied at all stages of the implementation of Industrial Internship activities, starting from planning Industrial Internship activities until the implementation of its program. It is even confirmed by Schermerhorn (2005) that when planning is done well it will have implications on the overall management process within the organization. When planning is done well it creates a solid platform for the other management functions: organizing, leading, and controlling.

\section{CONCLUSION}

The planning stage, the curriculum validation as preparatory activitydoes not involve the businessandindustry. Curriculum validation is only conducted by the SMKNegeri 5 Makassar with reference to the national curriculum. Mappingthe business and industrial isless systematically implemented which is related to the feasibility and appropriateness of Industrial Internship location with Industrial internship needs. Block model is established as anIndustrial Internship model by 
SMKNegeri 5 Makassar. The block release model is a training model in which the student's learning time is divided on a matter of months or semesters.

Organizing Industrial Internship is preceded by the formation of Industrial Internship committee which is held two months before Industrial Internshipimplemention and it is realized through Decree of school principal of SMKNegeri 5 Makassar. Delegation of tasks and responsibilities among the organizational organizers of the Industrial Internship committee has not been evenly distributed and there is a tendency to be dominated by the committee chairman. The appointment of Industrial Internship counselors is not absolutely based on teacher professionalism and competence, but it uses a combined method. In addition to aspects of mastery of skills competence and teaching experience, the aspect of equity is also one of the main considerations in preparing Industrial Internship counselors.

Implementation of Industrial Internship which begins with the student placement in business and industry has not been run in accordance with the purpose of Industrial Internship. Selection aspect of Industrial Internship locations still need to be addressed mainly related to the suitability of the field of expertise of students with the existing work conditions in the location. There are still many students who do not work in accordance with the vocational skills learned. Learning by doing and learning by experience are not running optimally. Withdrawal of Industrial Internship students and the process of students' picking up are not often carried out by supervising teachers. The task to pick up Industrial Internship students does not simply pick up students, it is to coordinate with business andindustry and simultaneously serves as sales marketing for schools. Industrial Internship certificates are not a proof of recognition of competencies held by students. Industrial Internship management, especially the implementation aspect of Industrial Internship has not run well.

Industrial Internship management, especially supervising and monitoring aspect has not run optimally. Monitoring is only executed on a limited basis during the implementation period of Industrial Internship.Based on the result of the study, it can be inferred that SMKNegeri 5 Makassar as an educational organization needs to make continuous improvement on the management process of Industrial internship, starting from the process of planning, organizing, implementing, monitoring and monitoring.

\section{REFERENCES}

Bateman, Thomas S \& Scott A. Snell, (2002) Management Competing in the New Era. New York: McGraw Hill Irwin.

Billet, Stephen. (2011) Vocational Education, Purposes, Traditions, and Prospects. New York: Springer Science Bussiness.

Bohlinger, Sandra, Ulrika Haake, Christian Helms Jorgensen, Hanna Toivianen, and Andreas Wallo, (eds) (2015) Introduction in Working and Learning in Times of Uncertainty Challenges to Adult, Professional and Vocational Education. Roterdam: ShensePublisers,

Daft, Richard L. (2008) Management, Eighth edition. Ohio: Thomson South-Western,

Department of Manpower, (2011) Data Base Manpower Makassar,

Dessler, Gary. Management: (2001) Leading people and organizations in the 21st century. New Jersey: Prentice Hall.

Djojonegoro.Wardiman. (1999) Human Resource Development: Through Vocational Secondary School (SMK). Jakarta: PT BalaiPustaka,

Dawn, (2017) Unemployed Scholar Make Miris, Monday, 30 January. 
Gessler, Michael and Anja Christina Hinrichs, (2015) Key Predictors of Learning Transfer in Continuing Vocational Training in Sandra Bohlinger, Ulrika Haake, Christian Helms Jorgensen,

hannaToivianen, and Andreas Wallo, (eds) Working and Learning in Times of UncertaintyChallenges to Adult, Professional and Vocational Education. Roterdam: ShensePublisers,

Hamalik, Oemar. (2007) Integrated Management Training Employment Approach. Jakarta: Earth Literacy.

Presidential Instruction (Inpres) No. 9 of 2016 (October 17, 2016) on the revitalization of SMK. Kompas, Millions of Unemployed Vocational Graduates,

Miles, Matthew B and A. Michael Huberman.(1992) Qualitative Data Analysis.TjetjepRohendiRohidi's translation. Jakarta: UI Press,

Mullins, Laurie J. (2005) Management and Organizational Behavior. England: Pearson Educational Limited,

OECD and GIZ, The 7th Annual Expert Meeting of the ESSSA and The 2nd Regional Policy Dialogue on TVET Personnel. Better Connecting the Skills System to the World of Work 7-8 OCTOBER 2015, Siem Reap, Cambodia.

Pakpahan, Jorlin. (2002) The Development of Vocational Secondary Education, DediSupriadi, ed. History of Technical and Vocational Education in Indonesia, Building Productive People. Jakarta: DikmenjurDitjenDikdasmen, Depdiknas,

Pardjono, (February 19, 2011) Industry Role in SMK Development Paper presented at Industrial Role Workshop on SMK Development, Yogyakarta,

Pozaic, SanjaCrncovic. (2009) Transition From School to Work: Internships and First Entry to The Labor Market in Croasia, (Eropean: Working Document),

PP no. 19 of 2005 on Natioanal Education Standards.

Schermerhorn, John R. JR, (2005) Management, Eight Edition. New York: John Wiley \& Sons, Inc., Sidi, IndraDjati. (2001) Toward a Learning Society. Jakarta: Paramadina,

Suyanto, Bagong. (October 19, 2016) Irony Graduates of SMK, Kompas,

Law of the Republic of Indonesia Number 20 of 2003 on National Education System, article 15.

Vaughan, Karen. (2012) The integration of work and learning in New Zealand: A Working Paper.Wellington: New Zealand Council for educational research,

Yin, Robert K. (2003) Case Study Research: Design and Methods. 3rdedition. California: Sage Publication, Inc., 